\title{
Molecular detection of vector-borne agents in cats in Southern Brazil
}

\author{
Detecção molecular de agentes transmitidos por vetores em felinos domésticos no Sul do Brasil \\ Daniela Pedrassani ${ }^{1 *}$ (DD; Juliano Biolchi ${ }^{1}$; Luiz Ricardo Gonçalves ${ }^{2}$; Natalia Serra Mendes ${ }^{2}$; \\ Diego Carlos de Souza Zanatto ${ }^{2}$; Ana Cláudia Calchi²; Rosangela Zacarias Machado²; Marcos Rogério André2

\begin{abstract}
${ }^{1}$ Departamento de Medicina Veterinária, Universidade do Contestado - UnC, Canoinhas, SC, Brasil
${ }^{2}$ Departamento de Patologia Veterinária, Faculdade de Ciências Agrárias e Veterinárias - FCAV, Universidade Estadual Paulista - UNESP,
\end{abstract} \\ Jaboticabal, SP, Brasil
}

Received May 24, 2019

Accepted September 03, 2019

\begin{abstract}
This study used serological and molecular methods to investigate the occurrence of vector-borne pathogens (VBP) with zoonotic potential in cats neutered at the University Veterinary Hospital in Canoinhas, Santa Catarina. The combined PCR and serological results revealed that 17 (56.6\%) cats were positive for one or more pathogens. The sampled cats had antibodies to Ehrlichia spp. (7/30), Anaplasma phagocytophilum (3/30) and Leishmania infantum (2/30). The PCR assay detected DNA closely related to Ehrlichia canis in 6/30 cats, Mycoplasma haemofelis in 2/30 cats, A. phagocytophilum and Cytauxzoon sp. in one cat each. While Bartonella clarridgeiae and B. henselae were detected in two cats each, and $B$. koehlerae was detected in one cat.
\end{abstract}

Keywords: Anaplasma, Bartonella, Ehrlichia, Leishmania, Mycoplasma, cat.

\section{Resumo}

Como os felinos podem ser parasitados por diversos patógenos transmitidos por vetores (PTV), alguns com caráter zoonótico, este estudo objetivou detectar por métodos sorológicos e moleculares, patógenos transmitidos por vetores hematófagos, em gatos atendidos em um Hospital Veterinário Universitário em Santa Catarina. Os resultados da PCR e da sorologia combinados, revelaram que 17 (56,6\%) gatos foram positivos para um ou mais patógenos. Na sorologia, foram positivos 7/30 gatos para Ehrlichia, 3/30 para Anaplasma phagocytophilum e 2/30 para Leishmania infantum. Na PCR foi detectado DNA filogeneticamente associado a: Ehrlichia canis em 6/30 gatos; Mycoplasma haemofelis, em 2/30 gatos; A. phagocytophilum e Cytauxzoon sp. em 1/30 gatos cada. Enquanto Bartonella clarridgeiae e B. henselae foram detectadas, cada uma, em dois gatos, $B$. koehlerae foi detectada em um gato.

Palavras-chave: Anaplasma, Bartonella, Ehrlichia, Leishmania, Mycoplasma, gato.

\section{Introduction}

Feline vector-borne diseases (FVBDs) are caused by a wide range of pathogens, including viruses, bacteria, protozoa, and helminths that are transmitted by blood-sucking arthropods, such as fleas, ticks, and flies (HARTMANN \& BERGMANN, 2017). The vector-borne diseases (VBDs) are becoming more common not only in humans, but also in dogs and cats (BANETH et al., 2012; MAIA et al., 2014; ANDRÉ et al., 2017) in Brazil (ANDRÉ et al., 2017) and worldwide (MAIA et al., 2014) as a result of changing climate. Some fvbds can be life-threatening for cats while others represent a major zoonotic concern (MAIA et al., 2014; ANDRÉ et al., 2015). Although the occurrence of Bartonella spp., Leishmania spp. and

*Corresponding author: Daniela Pedrassani. Departamento de Medicina Veterinária, Universidade do Contestado - UnC, Rua Roberto Ehlke, 86, CEP 89460-000, Canoinhas, SC, Brasil. e-mail: daniela@unc.br hemoplasmas has been extensively investigated among cats, further studies are necessary regarding the dispersion of Anaplasmataceae agents, piroplasmids and Hepatozoon spp. in domestic and stray cats (OTRANTO \& DANTAS-TORRES, 2010; ANDRÉ et al., 2017; GUIMARÃES et al., 2019).

Nowadays, the extensive contact between domestic cats and humans has favored the transmission of zoonotic agents. Therefore, it is crucial to increase the FVBP surveillance aiming at determining the real impact of these agents on Public Health (UDELL \& SHREVE, 2017). Currently, no data on vector-borne agents in cats is available in the municipality of Canoinhas, SC, southern Brazil, so molecular and serological methods were used to investigate the DNA presence and/or serological exposure to FVBP, namely Anaplasma, Ehrlichia, Babesia/Theileria, Bartonella, Mycoplasma, Cytauxzoon and Hepatozoon in domestic cats in this region. 


\section{Material and Methods}

\section{Population and studied area}

Blood and ectoparasite samples were collected from 30 apparently healthy domestic cats neutered at the Veterinary Hospital of the University of Contestado (UnC) in Canoinhas (latitude $26^{\circ} 10^{\prime} 38^{\prime \prime} \mathrm{S}$ and longitude 50'23' 24” W), SC, Brazil, between November and December 2017. The cats aged from 8 months to 7 years: 15 males (46.7\% were less than 2 years old, $40 \%$ between 2 and 5 years old and $13.3 \%$ with more than 5 years old) and 15 females ( $80 \%$ were less than 2 years old and $20 \%$ between 2 and 5 years old). All performed procedures followed the ethical guidelines of the Ethics Committee of the UnC (number 11/17). The owners answered a questionnaire regarding animal gender, breed, living conditions, age and use of acaricides/insecticides.

\section{Blood and ectoparasites sampling}

Blood samples were collected from the cephalic or jugular vein. A fraction of the sample was stored in DNAse and RNAse free sterile microtubes containing anticoagulant (EDTA) while another fraction was centrifuged to separate the serum. Both whole blood and serum samples were stored at $-20^{\circ}$.

Ectoparasite specimens were collected and preserved in $70 \%$ ethanol (Exodo Científica ${ }^{\circledR}$ ). Ticks and fleas were identified using previously described taxonomic keys (BICHO \& RIBEIRO, 1998; BARROS-BATTESTI et al., 2006).

\section{Hemogram and Giemsa-stained blood smears}

The hemogram was performed according to the routine technique. The leukocyte differential count and the search for the FVBP were performed manually in May-Grünwald-Giemsa - stained blood smears.

\section{FVBP molecular screening and characterization}

For the FVBP molecular screening and characterization, a $200 \mu \mathrm{L}$ whole blood aliquot from each cat was used to extract the DNA using the QIAamp DNA Blood Mini kit (QIAGEN ${ }^{\circledR}$, Valencia, CA, USA), following the manufacturer's instructions. The DNA concentration and quality were measured using the 260/280nm absorbance ratio $\left(\right.$ Nanodrop $^{\circledR}$, Thermo Fisher Scientific, Waltham, MA, USA). The amplifiable DNA was detected by a PCR assay targeting a fragment of mammalian glyceraldehyde-3-phosphate dehydrogenase ( $g a p d h)$, according to Birkenheuer et al. (2003).

The performed conventional PCR (cPCR) assays targeted the 16S rRNA gene of Ehrlichia (MURPHY et al., 1998), Anaplasma (MASSUNG et al., 1998), and Mycoplasma (MAGGI et al., 2013), and the 18S rRNA of Cytauxzoon sp. (BIRKENHEUER et al., 2006), Hepatozoon spp. (INOKUMA et al., 2002), Babesia spp. (JEFFERIES et al., 2007) and kinetoplast DNA Leishmania spp. (RODGERS et al., 1990; LOPES et al., 2016). Additionally, the cPCR also targeted gltA (BILLETER et al., 2011), rpoB
(DINIZ et al., 2007), ftsZ (PAZIEWSKA et al., 2011), and nuo $G$ gene fragments (ANDRÉ et al., 2015) of Bartonella spp. and the msp2 gene fragment (DRAZENOVICH et al., 2006) of A. phagocytophilum.

The DNA positive controls for Leishmania infantum (JUSI et al., 2015), Bartonella henselae (André et al., 2015), Mycoplasma sp. (GONÇALVES et al., 2015), Hepatozoon caimani (BOUER et al., 2017), Babesia vogeli (Jaboticabal strain), Cytauxzoon sp. (ANDRÉ et al., 2009), Ehrlichia canis (Jaboticabal strain), and Anaplasma sp. (BENEVENUTE et al., 2017) were obtained from naturally infected animals. Ultra-pure water (Nuclease-Free Water Promega ${ }^{\circledR}$, Wisconsin, USA) was used as a negative control in all PCR assays. The gels were imaged under ultraviolet light using the Image Lab Software, version 4.1 (Bio-Rad $\left.{ }^{\circledR}\right)$.

The reaction products of PCR-positive samples were purified using the Silica Bead DNA gel extraction kit (Thermo Fisher Scientific $^{\circledR}$, USA). Purified amplified DNA fragments were submitted to phylogenetic analysis and sequence confirmation using an automatic sequencer (ABI PRISM 3700 DNA Analyser/ Applied Biosystem $\left.^{\circledR}\right)$ in the Center for Biological Resources and Genomic Biology (CREBIO, Jaboticabal, São Paulo, Brazil). The sequences were aligned with GenBank data using the MAFFT software, version 7 (KATOH \& STANDLEY, 2013). Phylogenetic inference was based on Bayesian Inference (BI) analysis, using the MrBayes X-SEDE (3.2.6) (RONQUIST \& HUELSENBECK, 2003). All phylogenetic analyses used the CIPRES Science Gateway (MILLER, 2010). The trees were examined in Treegraph 2.0.56-381 beta (STOVER \& MULLER, 2010).

\section{Serological screening for selected FVBP}

The serological screening for FVBP was performed by the indirect fluorescence antibody test (IFAT) using slides sensitized with E. canis (ANDRÉ et al., 2010), A. phagocytophilum (SOUSA et al., 2017) and L. infantum (OLIVEIRA et al., 2008) antigens as previously described. Briefly, antigen slides were removed from storage and allowed to thaw at room temperature for $30 \mathrm{~min}$. Ten microliters of twofold serum dilutions (starting at 1:64, the cut-off for E. canis and A. phagocytophilum, and 1:80 for Leishmania infantum) were placed in the wells of antigen-sensitized slides. On each slide, serum samples from dogs naturally infected with E. canis (NAKAGHI et al., 2008) and L. infantum (OLIVEIRA et al., 2008) as well as from horses experimentally infected with $A$. phagocytophilum (SOUSA et al., 2017) were used as positive controls. Dog and horse serum samples negative to the studied VBP were kindly supplied by IMUNODOT Diagnostics Ltda. (Jaboticabal, SP, Brazil). Slides were incubated at $37^{\circ} \mathrm{C}$ in a moist chamber for $30 \mathrm{~min}$, washed three times in PBS ( $\mathrm{pH}$ 7.2) for $5 \mathrm{~min}$, and air dried at room temperature. Then, the slides were incubated with fluorescein isothiocyanate, labeled anti-cat $\operatorname{IgG}\left(\operatorname{Sigma}^{\circledR}\right.$, St. Louis, USA) in tested serum samples and anti-dog IgG and anti-horse IgG (Sigma ${ }^{\circledR}$, St. Louis, USA) in positive and negative control serum samples, which were diluted following the manufacturer instructions. These slides were incubated again at $37^{\circ} \mathrm{C}$, washed three times in PBS, once more in distilled water, and air dried 
at room temperature. Finally, slides were overlaid with buffered glycerin ( $\mathrm{pH} 8.7$ ), covered with glass coverslips, and examined in a fluorescence microscope (Olympus ${ }^{\circledR}$, Tokyo, Japan).

\section{Statistical analyses}

Data were not normally distributed according to the Shapiro-Wilk test. Therefore, the quantitative hematological variables of positive and negative FVBP groups were compared by the nonparametric Mann Whitney U-test, at $\mathrm{P}<0.05$.

\section{Results}

The May-Grünwald-Giemsa-stained blood smears $(\mathrm{n}=30)$ showed no inclusions suggestive of FVBP. However, the PCR and IFAT techniques detected FVBP and the results are shown in Table 1. Of the 30 domestic cats, 17 (56.6\%) were positive to at least one FVBP by either serological or molecular techniques. Among cats positive for only one agent, Ehrlichia spp. was the

Table 1. FVBP positive cats according to the results of the serological and molecular techniques used in this study.

\begin{tabular}{llcc}
\hline \multirow{2}{*}{ Pathogen } & \multicolumn{3}{c}{ Number of positive cats (\%) } \\
\cline { 2 - 4 } & PCR & IFAT & Total \\
\hline Ehrlichia spp. & $6(20.0)$ & $7(23.3)$ & $11(36.6)$ \\
Anaplasma spp. & $1(3.3)$ & $3(10.0)$ & $4(13.3)$ \\
Bartonella spp. & $4(13.3)$ & - & $4(13.3)$ \\
Mycoplasma spp. & $2(6.6)$ & - & $2(6.6)$ \\
Leishmania spp. & $0(0.0)$ & $2(6.6)$ & $2(6.6)$ \\
Cytauxzoon spp. & $1(3.3)$ & - & $1(3.3)$ \\
Hepatozoon spp. & $0(0.0)$ & - & $0(0.0)$ \\
Babesia spp. & $0(0.0)$ & - & $0(0.0)$ \\
\hline
\end{tabular}

most common pathogen (36.6\%), followed by Anaplasma spp. and Bartonella spp. (13.3\% each), and Mycoplasma spp. and Leishmania spp. (6.6\% each) (Table 1). Five cats were positive to at least two pathogens from different genera (Table 2). Despite this, all cats were considered healthy based on history, physical examination and body condition scores.

According to the owners, $76.6 \%$ of the cats were not controlled for ectoparasites. A total of $80 \%$ (24/30) of the cats had parasites, of which $95.8 \%$ (23/24) were parasitized by fleas of the species Ctenocephalides felis Bouché, 1835, and 4.2\% (1/24) was parasitized by an adult female tick, Amblyomma aureolatum Pallas, 1772.

The owners reported that most cats did not have a history of recent fights $(83.3 \%)$, were not aggressive with people $(76.7 \%)$, had access to the street $(80 \%)$, and lived with other cats $(83.3 \%)$.

Furthermore, the hematological results indicated that the monocyte count was significantly lower in FVBP-free cats (Table 3), whereas monocytosis was observed in two cats seropositive for FVBP.

Out of 30 samples, two (6.6\%) were positive for $M$. haemofelis. The cluster was composed of $M$. haemofelis $16 \mathrm{~S}$ rRNA sequences previously detected in domestic cats in Switzerland, Australia, and the United Kingdom (Figure 1).

Seven cats $23.1 \%$ (7/30) were positive for E. canis with the following titers: 64 (six animals) and 128 (one animal). Further, six animals (19.8\%) were positive for Ehrlichia spp. in the $16 \mathrm{~S}$ rRNA PCR assay, of which two cats $(6.6 \%)$ were also positive in the IFAT. The only tick found was collected from an E. canis seropositive cat. Although apparently healthy, $54.5 \%$ of the positive animals for Ehrlichia (PCR and/or IFAT) had hematological disorders such as lymphopenia (27.27\%), neutropenia (9.09\%) and hyperproteinemia (18.18\%). The phylogenetic analysis indicated that the Ehrlichia 16S rRNA sequences (seq. 1, 2 and 3) detected in three different cats were closely related to the $E$. canis sequences identified in a domestic cat (MH234591) in Brazil and in ticks in

Table 2. FVBP co-positivity assessed by molecular and serological techniques in blood samples of cats in Canoinhas, SC, Brazil.

\begin{tabular}{lc}
\hline \multicolumn{1}{c}{ Pathogens detected (Diagnostic technique) } & Total of positive cats (\%) \\
\hline Ehrlichia spp. (IFAT) + Bartonella spp. (PCR) & $2(6.6)$ \\
Ehrlichia spp. (PCR) + Bartonella spp. (PCR) & $1(3.3)$ \\
Ehrlichia spp. (PCR) + Cytauxzoon spp. (PCR) & $1(3.3)$ \\
Ehrlichia spp. (PCR/ IFAT) + Bartonella spp. (PCR) + Leishmania spp. (IFAT) & $1(3.3)$ \\
Ehrlichia spp. (IFAT) + Mycoplasma spp. (PCR) + Anaplasma spp. (IFAT) & \\
\hline
\end{tabular}

Table 3. Mean \pm Std. Error of Mean (SE) for the hematological parameters of domestic felines -positive and negative for FVBP.

\begin{tabular}{|c|c|c|c|c|}
\hline \multirow{2}{*}{ Parameter } & Ranges for healthy cats & Positive (n=17) & Negative $(n=13)$ & P-value \\
\hline & (Weiss, Wardrop, 2010) & $($ mean \pm SE $)$ & $($ mean $\pm S E)$ & (test) \\
\hline Hematocrit (\%) & $24-45$ & $42.71 \pm 1.53$ & $39.62 \pm 1.59$ & 0.171 \\
\hline $\mathrm{RBC}$ count $\left(\mathrm{x} 10^{6} / \mathrm{mL}\right)$ & $5.0-10.0$ & $7.8 \pm 0.30$ & $7.3 \pm 0.28$ & 0.291 \\
\hline WBC count $\left(\mathrm{x} 10^{3} / \mathrm{mL}\right)$ & $5,500-19,500$ & $10,065 \pm 821.9$ & $11,862 \pm 1,326$ & 0.298 \\
\hline Band neutrophils & $0-300$ & $110.6 \pm 32.3$ & $66.81 \pm 34.4$ & 0.232 \\
\hline Segmented neutrophils & $2,500-12,500$ & $5,486 \pm 688.4$ & $7,154 \pm 1211$ & 0.298 \\
\hline Lymphocytes & $1,500-7,000$ & $3,757 \pm 523.6$ & $4,294 \pm 690.4$ & 0.532 \\
\hline Monocytes & $0-850$ & $293.3 \pm 75.0$ & $148.6 \pm 63.8$ & 0.046 \\
\hline Eosinophils & $0-1,500$ & $311 \pm 42.6$ & $198.3 \pm 46.0$ & 0.085 \\
\hline PPT & $5.4-7.8$ & $7.08 \pm 0.22$ & $6.71 \pm 0.14$ & 0.205 \\
\hline
\end{tabular}

Note: No significant difference was observed between groups for the Mann-Whitney $(\mathrm{U})$ at $\mathrm{p} \geq 0.05$. 


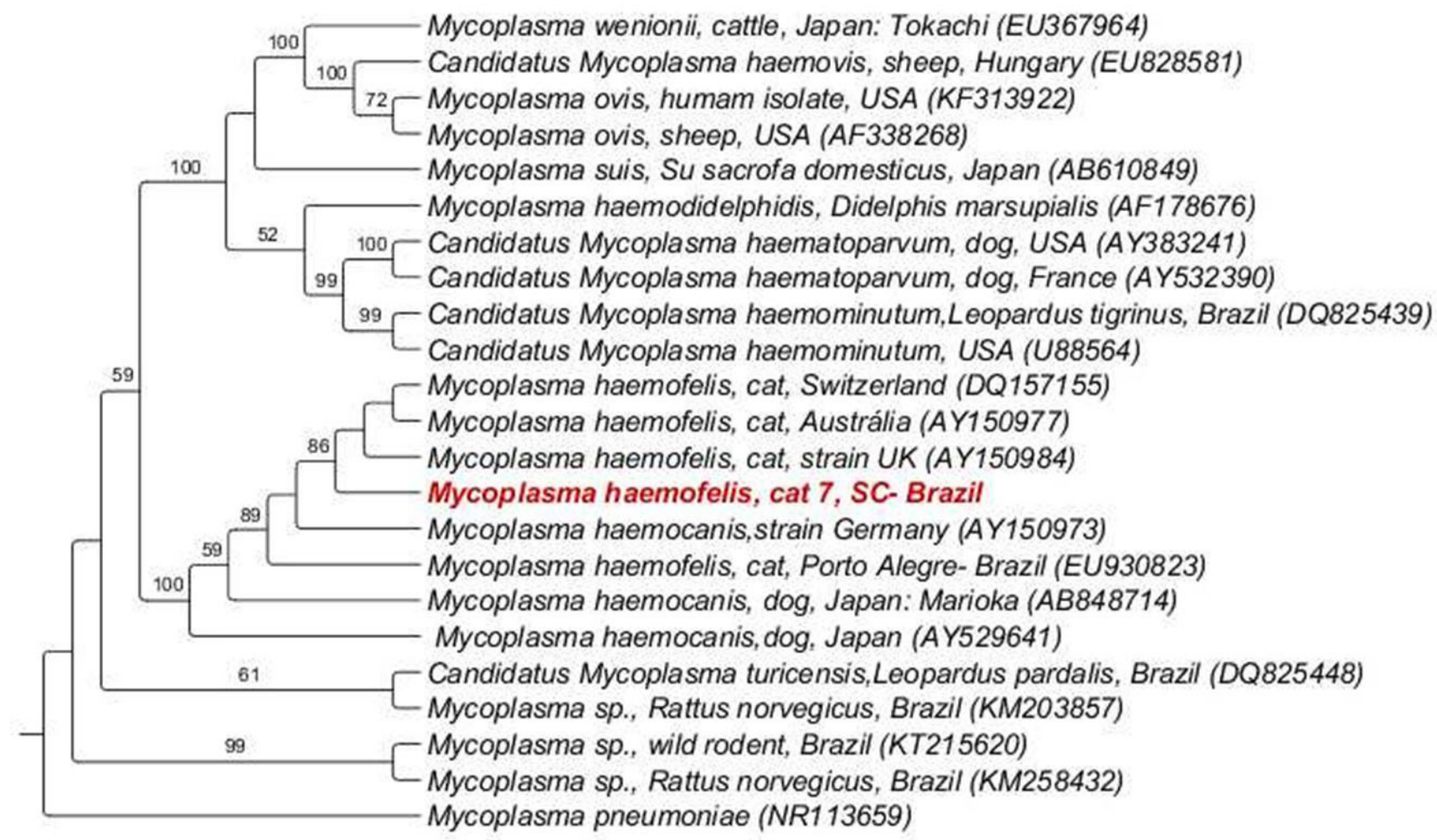

Figure 1. Phylogenetic relationships based on the sequence of 16S rRNA fragment amplified from Mycoplasma species isolated from domestic cats, compared with known species of the genus Mycoplasma. The phylogenetic tree was constructed from 1.300 bp sequences, inferred using the Bayesian method and GTRGAMMA+I evolutionary model. Numbers at nodes correspond to Bayesian posterior probabilities over 50 , using Mycoplasma pneumoniae (NR113659) as outgroup.

the USA (MF059355) and Mexico (MG029082), supported by a high Bayesian posterior probability (100\%) (Figure 2).

One cat was positive for Anaplasma spp. in the $16 \mathrm{~S}$ rRNA nPCR but negative to $A$. phagocytophilum in the msp-2 qPCR assay. Three cats seropositive for $A$. phagocytophilum had titers ranging from 64 to 512 but none was positive for Anaplasma spp. in both PCR and IFAT.

The phylogenetic analysis indicated that the Anaplasma $16 \mathrm{~S}$ rRNA sequence is phylogenetically related to $A$. phagocytophilum. The phylogenetic relationships inferred by Bayesian analysis indicated five main clades, supported by posterior probabilities ranging from 54.2 to $99.8 \%$ (Figure 3). The sequence detected in a domestic cat in Santa Catarina, in the present study, was positioned in the main clade comprising the $A$. phagocytophilum/Anaplasma spp. sequences previously detected in animals and ticks in Brazil and worldwide, corroborating the BLASTn analysis, which indicated $100 \%$ identity with a sequence of Anaplasma sp. previously detected in a domestic cat in Brazil.

Two of the four positive cats for Anaplasma spp. (IFAT or PCR) had anemia, neutropenia, monocytosis, hypoproteinemia, and lymphopenia.

In this study, 13.3\% (4/30) of the sampled cats had Bartonella spp. DNA. The four qPCR (nuo $G$ ) positive samples for Bartonella spp were also positive for at least one targeted gene in CPCR assays. All four were positive for the glt $A$ gene, three for the fts $Z$ gene and three for the rpoB gene. The sampled animals, sequencing confirmed B. clarridgeiae $(6.6 \%, 2 / 30)$, B. henselae $(6.6 \%, 2 / 30)$ and $B$. koehlerae $(3.3 \%, 1 / 30)$ infections. The analysis on the sequenced products showed that they presented $99.8-100 \%$ identicalness with $B$. henselae (access numbers MF314832, KY913627 and KX499336); 100\% with B. clarridgeiae (access number KY913636) and 100\% with B. koehlerae (access numbers FJ832089 and AF176091) (Table 4). Cases in which glt $A$ and $r p o B$ sequences from a single cat corresponded to different feline Bartonella species were considered coinfections. Therefore, one cat $(3.3 \%, 1 / 30)$ was concurrently infected with B. clarridgeiae and $B$. henselae.

The $B$. clarridgeiae glt $A$ sequences amplified in this study were closely positioned to sequences previously detected in fleas in Chile (KY913636) and in a cat in Thailand (KX001761), supported by a $100 \%$ posterior probability. Additionally, the amplified $B$. koehlerae gltA sequence detected in cat \#29 was closely related to a $B$. koehlerae sequence (AF176091) detected in a cat in the USA, supported by a high Bayesian posterior probability of $100 \%$. The detected $B$. henselae sequence was closely related to a $B$. henselae sequence (AF176091) previously detected in fleas in Chile (KY913627), supported by a high Bayesian posterior probability of $100 \%$ (Figure 4).

The Bartonella koehlerae rpoB sequence was positioned near to B. koehlerae sequences detected in a dog in Israel (FJ832089), 


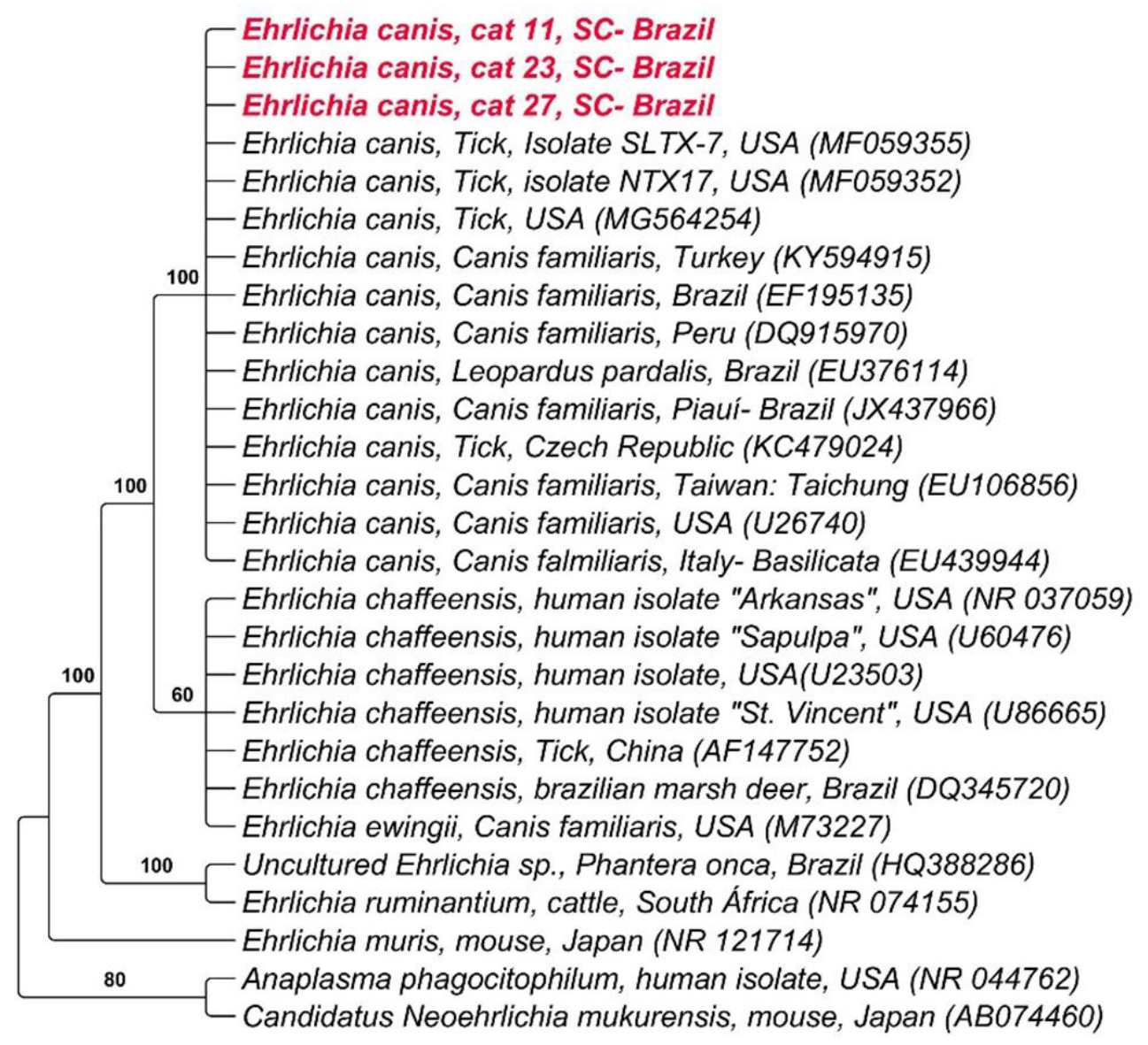

Figure 2. Phylogenetic relationships based on the sequence of $16 \mathrm{~S}$ rRNA fragment amplified from Ehrlichia species isolated from domestic cats, compared with known species of the genus Ehrlichia. The phylogenetic tree was constructed from 350 bp sequences, inferred using the Bayesian method and GTRGAMMA+I evolutionary model. Numbers at nodes correspond to Bayesian posterior probabilities over 50, using Anaplasma phagocytophilum (NR044762) and 'Candidatus Neoehrlichia mikurensis'(AB074460) as outgroups.

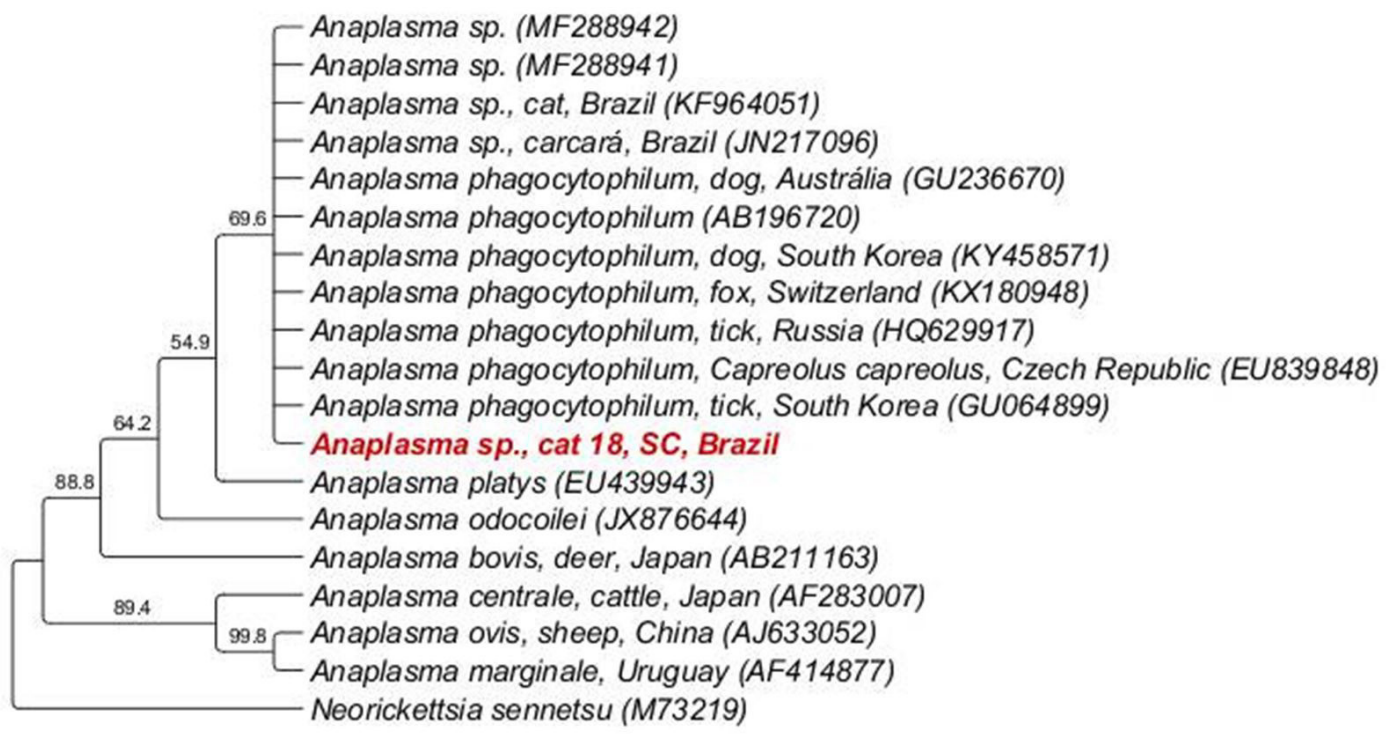

Figure 3. Phylogenetic relationships based on the sequence of $16 \mathrm{~S}$ rRNA fragment amplified from Anaplasma species isolated from domestic cats, compared with known species of the genus Anaplasma. The phylogenetic tree was constructed from 932 bp sequences, inferred using the Bayesian method and GTR+G+I evolutionary model. Numbers at nodes correspond to Bayesian posterior probabilities over 50, using Neorickettsia sennetsu (M73219) as outgroup. 
supported by $100 \%$ posterior probability. In addition, the amplified $B$. henselae rpo $B$ sequences are closely related to $B$. henselae sequences previously detected in Rattus rattus Linnaeus, 1758 in New Zealand (MF 314832) and a cat in New Caledonia (JN646670), supported by a high Bayesian posterior probability of 100\% (Figure 5).

Finally, the amplified $B$. henselae fts $Z$ sequences were closely related to $B$. henselae sequences previously detected in Acinonyx jubatus Schreber, 1775 in Zimbabwe (KX499336) and in a cat in Guatemala (KP822812), supported by high Bayesian posterior probability of $100 \%$ (Figure 6). The amplified fts $Z$ B. koehlerae sequence detected in the cat \#29 presented $100 \%$ identity with a Bartonella sp. previously detected in Leopardus wiedii Schinz, 1821 from Brazil (GU903912), and was closely related to B. koehlerae from Panthera leo Linnaeus, 1758 from South Africa (KX499334) and to Bartonella sp. from a margay from Brazil (GU903912), supported by a Bayesian posterior probability of $75 \%$ (Figure 6 , Table 4).
A concatenated phylogenetic tree of the genes was constructed to achieve more robust support to identify Bartonella species in this study. The amplified $B$. henselae sequences detected in cats \#6 and \#15 were closely related to $B$. henselae strain Houston-1 (BX897699), supported by a high Bayesian posterior probability of $99-100 \%$. The amplified B. koeblerae sequence detected in cat \#29 was closely related to B. koehlerae C-29 (KL407334) supported by a high Bayesian posterior probability of 100\% (Figure 7).

Two cats were seropositive for L. infantum, with 80 and 160 titers. However, all 30 cats (including the two positives) were negative for L. infantum based on the PCR assay targeting the kinetoplast DNA. Even though one cat $(3.3 \%)$ was positive to Cytauxzoon sp. in the $18 \mathrm{~S}$ rRNA cPCR, the low amount of amplified DNA resulted in weak band intensity in agarose gel electrophoresis, precluding a high-quality sequencing.

None of the sampled cats was positive for either Babesial Theileria spp. or Hepatozoon spp. in the PCR assays.

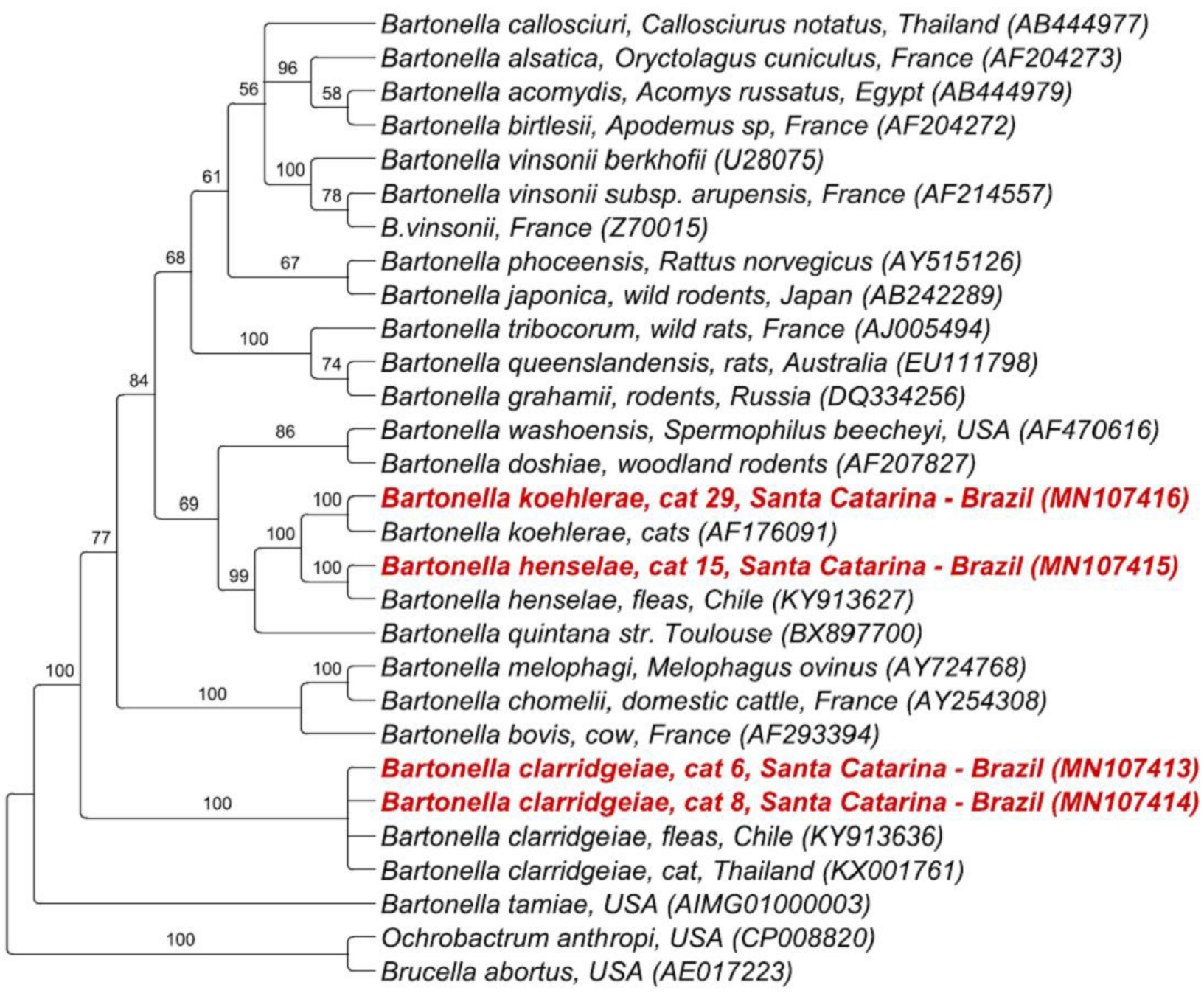

Figure 4. Phylogenetic relationships based on the sequence of a citrate synthase ( $\mathrm{glt} A$ ) gene fragment amplified from Bartonella species isolated from domestic cats, compared with known species of the genus Bartonella. The phylogenetic tree was constructed from $767 \mathrm{bp}$ sequences, inferred using the Bayesian method and GTR+G+I evolutionary model. Numbers at nodes correspond to Bayesian posterior probability over 50, using Brucella abortus and Ochrobactrum anthropi as outgroups. 


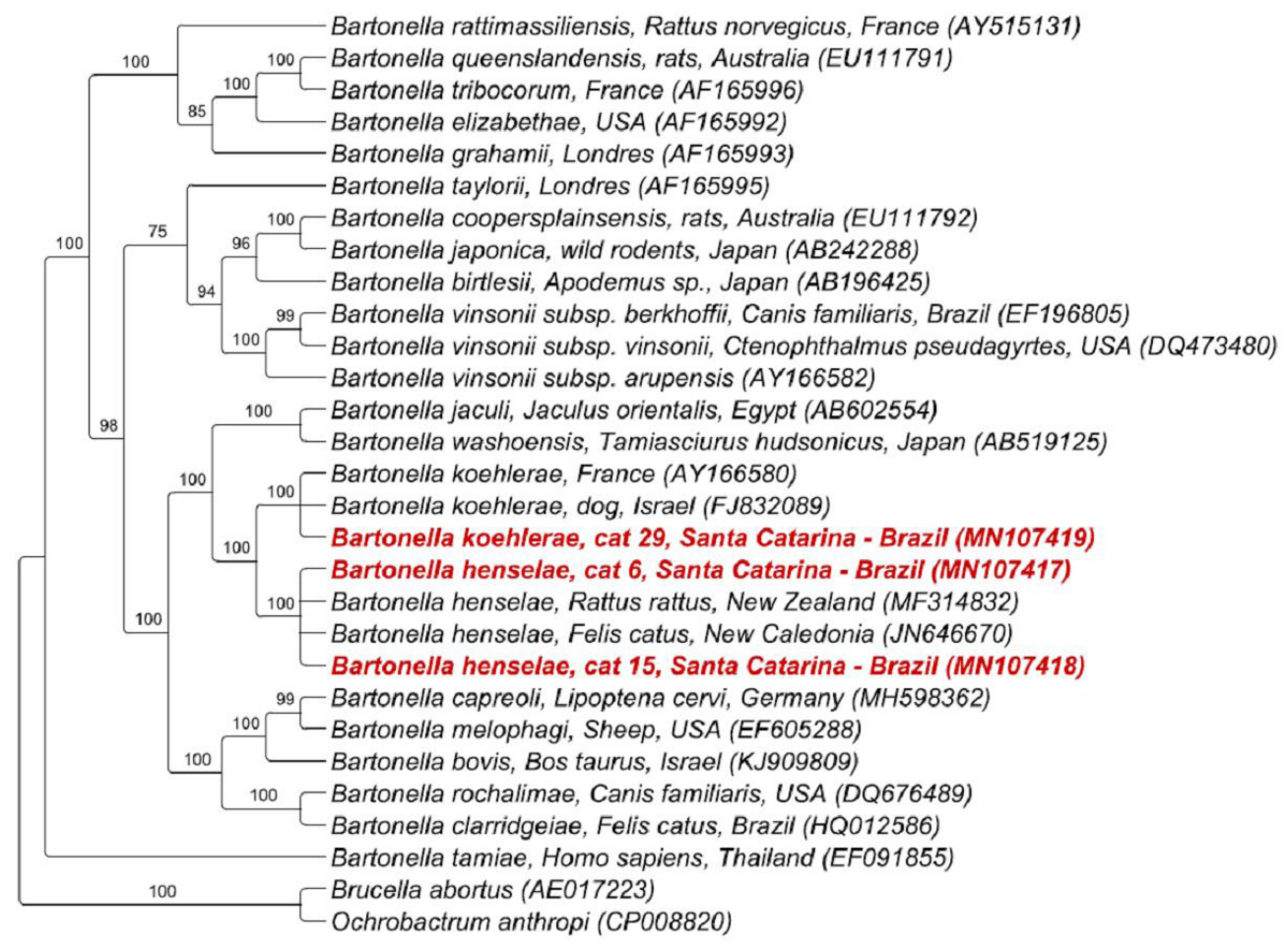

Figure 5. Phylogenetic relationships based on the sequence of a rpoB gene fragment amplified from Bartonella species isolated from domestic cats, compared with known species of the genus Bartonella. The phylogenetic tree was constructed from 720 bp sequences, inferred using the Bayesian method and GTR+G+I evolutionary model. Numbers at the nodes correspond to Bayesian posterior probability over 80 , using Brucella abortus and Ochrobactrum anthropi as outgroups.

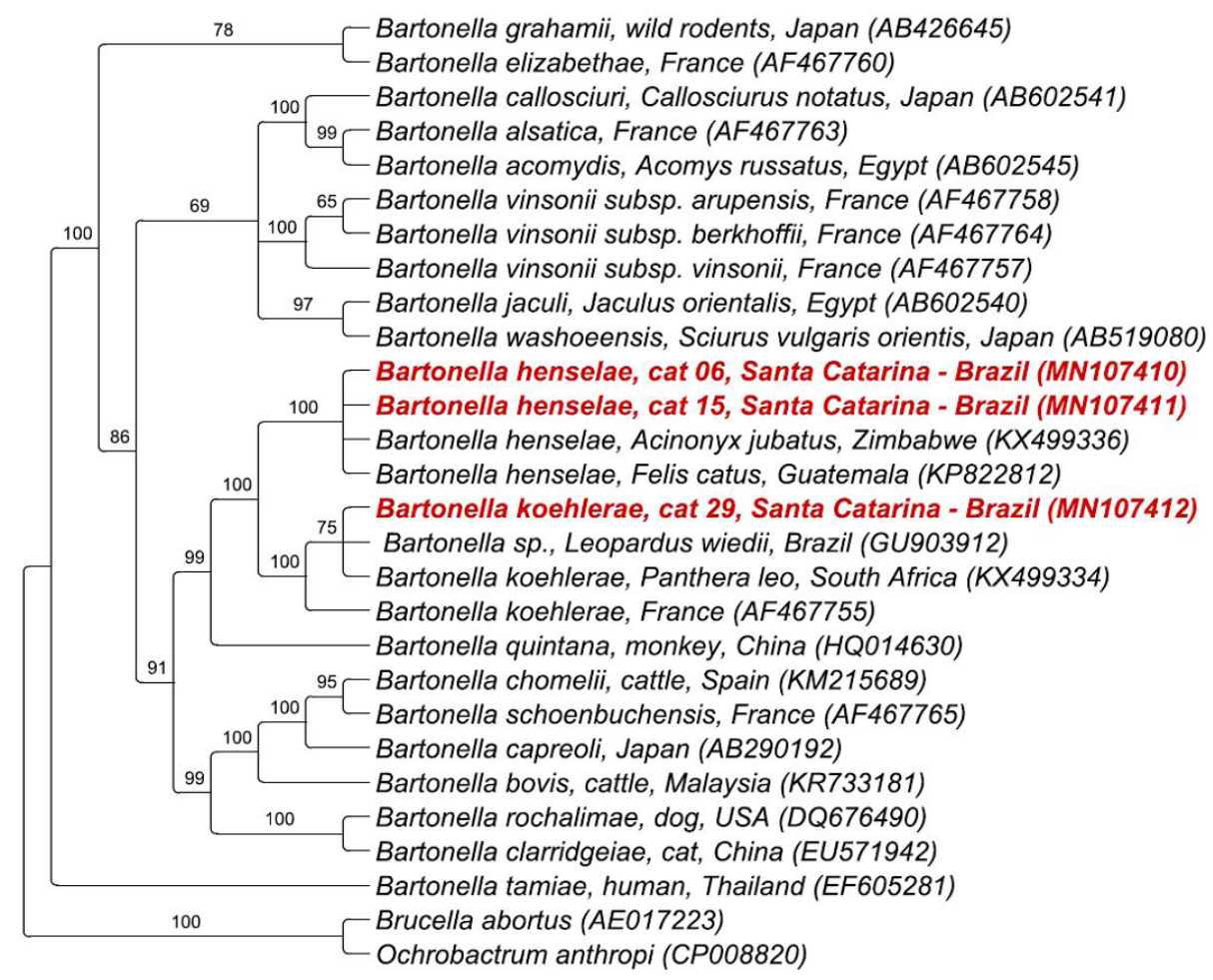

Figure 6. Phylogenetic relationships based on the sequence of a fts $Z$ gene fragment amplified from Bartonella species isolated from domestic cats, compared with known species of the genus Bartonella. The phylogenetic tree was constructed from 600 bp sequences, inferred using the Bayesian method and GTR+G+I evolutionary model. Numbers at the nodes correspond to Bayesian posterior probability over 80 , using Brucella abortus and Ochrobactrum anthropi as outgroups. 
Table 4. Bartonella species identified in cats sampled in Canoinhas, State of Santa Catarina, southern Brazil, according to conventional PCR assays based on three different genes and BLAST analysis.

\begin{tabular}{cccc}
\hline \multirow{2}{*}{ Cat ID } & \multicolumn{3}{c}{ \% identity according to Blast analysis (GenBank ID) } \\
\cline { 2 - 4 } & rpoB gene & gltA gene & ftsZ gene \\
\hline $\mathbf{6 0}$ & $100 \%$ B. henselae (MF314832) & $100 \%$ B. clarridgeiae (KY913636) & $99,81 \%$ B. henselae (KX499336) \\
$\# \mathbf{1 5}$ & negative & $100 \%$ B. clarridgeiae (KY913636) & negative \\
\#29 & $100 \%$ B. henselae (MF314832) & $100 \%$ B. henselae (KY913627) & $100 \%$ B. henselae (KX499336) \\
& $100 \%$ B. koehlerae (FJ832089) & $100 \%$ B. koeblerae (AF176091) & $100 \%$ Bartonella sp. (GU903912) \\
\hline
\end{tabular}
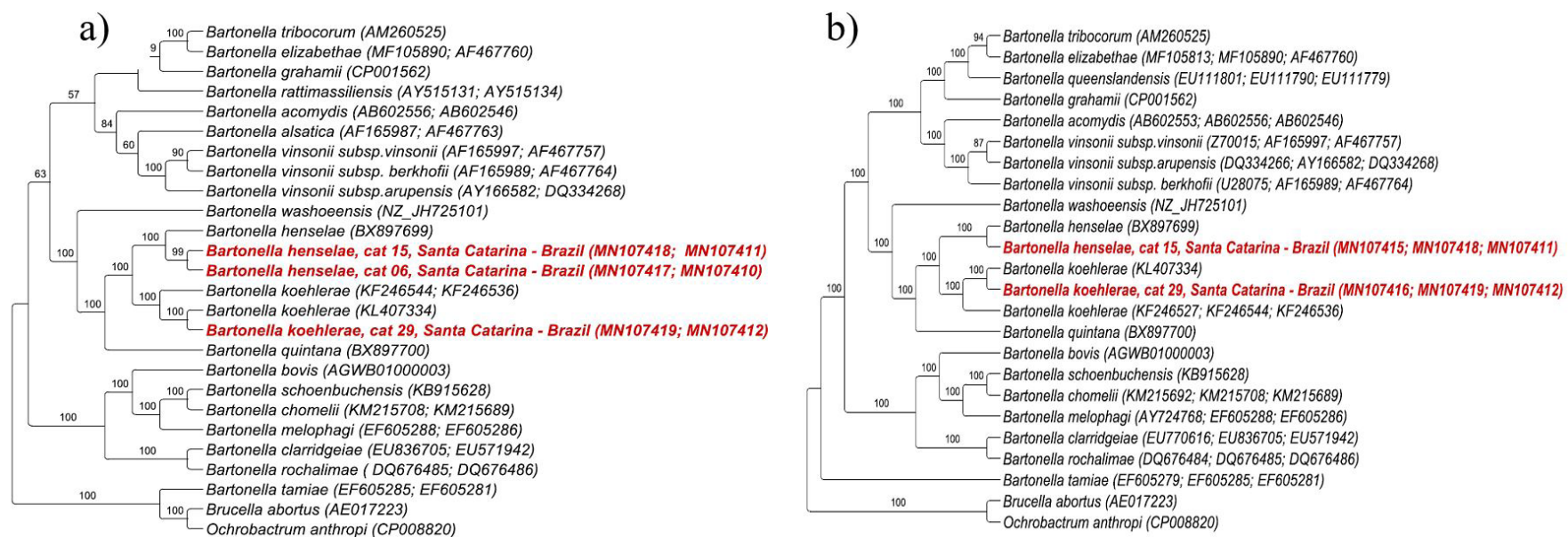

Figure 7. Concatenated phylogenetic analysis of Bartonella sequences: a) rpoB and fts $Z$ sequences (4902 bp after alignment), b) rpoB, gltA and $f$ ts $Z$ sequences (6294 bp after alignment), based on the topology generate on the Bayesian method. The values of support of posterior probability than 50\% are shown in each branch, using Brucella abortus and Ochrobactrum anthropi as outgroups.

\section{Discussion}

The FVBP geographical distribution and prevalence are on the rise worldwide (BANETH et al., 2012; ANDRÉ et al., 2017) while an increasing number of FVBP has been detected in humans (SANTOS et al., 2008; EYER-SILVA et al., 2017). No molecular studies investigating FVBP in cats had been previously conducted in the Canoinhas municipality, SC, southern Brazil. The results of the IFAT and PCR assays revealed a wide variety of FVBP species such as Mycoplasma, Ehrlichia, Anaplasma, Bartonella, and Cytauxzoon in household cats of the region. The low number of cats sampled in the present study, an acknowledged limitation of this work, precludes any statistical inference on the real prevalence of FVBP in the studied area.

Ehrlichia canis was the most common FVBP detected in this study and, interestingly, the only cat parasitized by an Amblyomma tick was positive for this pathogen as well. The seropositivity found in the present study suggests the exposure to Ehrlichia spp. in a feline population studied. However, the occurrence of cross-reactivity with other Anaplasmataceae family agents cannot be ruled out (WEN et al., 1997; ORTUÑO et al., 2005). Ehrlichia canis-like DNA was also detected in domestic cats in Mato Grosso (BRAGA et al., 2014b), Mato Grosso do Sul (ANDRÉ et al., 2015), Rio Grande do Norte (ANDRÉ et al., 2017), and Rio de Janeiro (GUIMARÁES et al., 2019), and in wild felids maintained in captivity in the state of São Paulo and in the Federal District (ANDRÉ et al., 2010; 2012).
Of the 11 cats positive for Ehrlichia, two (one positive in PCR and another positive in IFAT) had hyperproteinemia, which has also been found in E. canis seropositive cats in Rio de Janeiro (GUIMARÁES et al., 2019). In fact, this finding may be attributed to the increase of gamma globulins concentration during the febrile stage and persistence during subclinical and chronic stages of monocytic canine ehrlichiosis (RISTIC \& HOLLAND, 1993). Lymphopenia was also observed in seropositive cats to Ehrlichia spp. in Mato Grosso (BRAGA et al., 2013) whereas the authors in the present study observed that positive cats to Ehrlichia sp. in PCR tended to be lymphopenic.

The Bartonella species detected in the cats sampled in Canoinhas suggests that these animals may act as a source of infection to humans via scratching contaminated with flea feces or bites contaminated with infected blood (PENNISI et al., 2013).

Herein, B. henselae, B. clarridgeiae and B. koehlerae were detected in cats in the present study. Bartonella spp., an increasingly important Gram-negative intracellular bacteria in veterinary and human medicine (HARTMANN \& BERGMANN, 2017), was detected in four $C$. felis-infested cats. In fact, fleas are the main vector for $B$. henselae among cats (CHOMEL \& KASTEN, 2010). Bartonella henselae, the agent of the cat scratch disease (CSD), has been frequently reported in cats, which are considered the major reservoir for human infection (PENNISI et al., 2013). On the other hand, Bartonella clarridgeiae has been incriminated as a minor causative agent of CSD (CHOMEL \& KASTEN, 2010). Indeed, $B$. henselae and $B$. clarridgeiae have been already detected in domestic cats in other Brazilian states (BRAGA et al., 
2012a, 2015; MICELI et al., 2013; ANDRÉ et al., 2014, 2015). Additionally, B. henselae (PITASSI et al., 2015) and B. clarridgeiae (VIEIRA-DAMIANI et al., 2015) have been detected in blood donors in Brazil, raising suspicions regarding Bartonella transmission among humans via blood transfusion (SILVA et al., 2016).

Previously, a small Bartonella-gltA sequence fragment (96-bp) sharing $99 \%$ identity with $B$. koehlerae was detected in a margay (L. wiedii) maintained in captivity in a Brazilian zoo (FILONI et al., 2012). Recently, B. koehlerae was detected in cats in Rio de Janeiro (RAIMUNDO et al., 2019). Although B. koehlerae has been isolated from cat blood, the routes of transmission among cats have not been fully established yet (PENNISI et al., 2013).

The 16S rRNA-Anaplasma genotypes closely related to A. phagocytophilum have been detected in little-spotted-cats, Leopardus pardalis Linnaeus, 1758 (ANDRÉ et al., 2012), stray cats (ANDRÉ et al., 2014; 2017), coatis (SOUSA et al., 2017), and wild birds (MACHADO et al., 2012; WERTHER et al., 2017) in Brazil. However, in the present study, the sampled animals were negative for A. phagocytophilum in msp-2-qPCR assays, indicating that an Anaplasma genotype closely related to the human granulocytic anaplasmosis agent circulates in South America (ANDRÉ, 2018). Similarly, the cat \#18 was negative for $A$. phagocytophilum in $m s p-2$ qPCR, despite presenting a $16 \mathrm{~S}$ rRNA Anaplasma genotype closely related to $A$. phagocytophilum. The Anaplasma-positive cat in this study had no hematological disorders, corroborating the report by Pennisi et al. (2017) that cats seem to remain chronic carriers after infected with $A$. phagocytophilum.

There are few reports on the occurrence of piroplasmids among cats in Brazil (ANDRÉ et al., 2014, 2015, 2017; MALHEIROS et al., 2016). Regarding the molecular detection of piroplasmids, one cat was positive for Cytauxzoon sp. whereas none was positive for Babesia/Theileria spp. Even though 18S rRNA Cytauxzoon sp. closely related to Cytauxzoon felis has already been detected in cats in Mato Grosso do Sul (ANDRÉ et al., 2015), Rio de Janeiro (MAIA et al., 2013), and Rio Grande do Norte (ANDRÉ et al., 2017), clinical cytauxzoonosis has never been described in domestic cats in Brazil so far. Nonetheless, fatal cytauxzoonosis was reported among lions maintained in captivity in a zoo in Volta Redonda, Rio de Janeiro (PEIXOTO et al., 2007). While neotropical wild felids have been incriminated as potential reservoirs for Cytauxzoon spp. in Brazil (ANDRÉ et al., 2009; FURTADO et al., 2017), the vectors remain unknown in South America (ANDRÉ et al., 2017). Similarly, though there are reports on cats being infected with both Babesia vogeli (ANDRÉ et al., 2014, 2015; MALHEIROS et al., 2016) and Theileria spp. associated with ruminants and equids (ANDRÉ et al., 2014, 2015) in Brazil, the clinical relevance of these findings is unknown.

Likewise, Hepatozoon spp. has been scarcely reported in cats in Brazil. For instance, H. felis (BORTOLI et al., 2011; BRAGA et al., 2016) and Hepatozoon sp. closely related to $H$. americanum (ANDRÉ et al., 2015) have been reported in cats in Brazil. The real clinical significance of these infections deserves further investigation.

Albeit the absence of Leishmania DNA in whole blood samples from seropositive cats has been previously reported (BRAGA et al., 2014a; COURA et al., 2018), feline leishmaniasis is an emergent feline disease (PENNISI \& PERSICHETTI, 2018). And, even though the role of cats in the epidemiological cycles of leishmaniasis remains unclear, they may act as a reservoir for this parasite since sandflies feed on them (COURA et al., 2018). In Santa Catarina state, two autochthonous cases of canine visceral leishmaniasis were first detected in 2010 (FIGUEIREDO et al., 2012) while the first autochthonous case of human visceral leishmaniasis was diagnosed in 2017 (SMS, 2017), both in Florianópolis city. Because Canoinhas is not an endemic area for visceral leishmaniasis, we did not expect to find animals seropositive for Leishmania spp. The positive results in serology may be explained by serological cross-reactions between Leishmania and Trypanosoma species, as previously reported in dogs (LONGONI et al., 2012).

Hemoplasmas are one of the most prevalent flea-borne bacterial pathogens in cats (SHAW et al., 2004). In this study, despite two cats being infected with $M$. haemofelis, the most pathogenic hemoplasma, the erythrocyte count was within the reference values in both cats, albeit one had lymphopenia. According to Tasker et al. (2018), M. haemofelis chronic infection is usually not associated with significant anemia and carrier cats may show no evidence of anemia. Although 'Candidatus Mycoplasma haemominutum' is the most frequent hemoplasma species found in cats (BRAGA et al., 2012b; ANDRÉ et al., 2014; TASKER et al., 2018), often associated with chronic or subclinical infections (HARTMANN \& BERGMANN, 2017; TASKER et al., 2018), this agent was not detected in the cats of this study. Since blood-sucking arthropods (ticks and fleas) are suspected to be the vectors of feline hemoplasmas among domestic cats (SHAW et al., 2004; TASKER et al., 2018), and flea infestation was quite common in the sampled cats, including those positive for hemoplasmas, it is most likely that fleas acted as hemoplasma-vectors to these animals.

Furthermore, five cats were simultaneously positive for Ehrlichia and other FVB pathogens, such as Bartonella, Cytauxzoon, and Mycoplasma. Previously, co-positivity to Ehrlichial Anaplasmal Cytauxzoon and Mycoplasma was reported in two cats in Rio Grande do Norte (ANDRÉ et al., 2017); to Cytauxzoon and 'Candidatus Mycoplasma haemominutum' in one cat in Rio de Janeiro (MAIA et al., 2013), and to 'Candidatus Mycoplasma haemominutum' and Babesia vogeli, Bartonella spp., and to 'Candidatus Mycoplasma turicensis' or Mycoplasma haemofelis in stray cats in São Paulo (ANDRÉ et al., 2014). André et al. (2017) concluded that most likely that co-positivity is frequent in cats living in geographic areas where the competent vectors are present. According to these authors, the effect of multiple arthropod-borne hemoparasites in the pathogenesis of feline vector-borne diseases warrants further investigation. Although FBVP-positive cats were apparently healthy in the present study, veterinarians should keep in mind that cats co-positive to multiple FVBP may present a non-specific disease, which may further complicate the diagnosis, treatment and prognosis (BANETH et al., 2012; MAIA et al., 2014; ANDRÉ et al., 2017).

\section{Conclusion}

The results allow concluding that apparently healthy cats, with no clinical signs of infection, are exposed to multiple FVBP in the Canoinhas region, southern Brazil. The adoption of effective 
prophylaxis and control measures against arthropod vectors is much needed to prevent infection of cats, as well as the potential transmission to other animals and humans.

\section{Acknowledgments}

The authors are grateful to FAPESP (Foundation for Research Support State of São Paulo - Process 2015/02753-0) and CNPq for the financial support to MRA and PIBIC. MRA is a fellowship researcher of the "National Council for Scientific and Technological Development” (CNPq Process number 302420/ 2017-7).

\section{References}

André MR, Adania CH, Machado RZ, Allegretti SM, Felippe PAN, Silva KF, et al. Molecular detection of Cytauxzoon spp. in asymptomatic Brazilian wild captive felids. J Wildl Dis 2009; 45(1): 234-237. http:// dx.doi.org/10.7589/0090-3558-45.1.234. PMid:19204356.

André MR, Adania CH, Machado RZ, Allegretti SM, Felippe PAN, Silva $\mathrm{KF}$, et al. Molecular and serologic detection of Ehrlichia spp. in endangered Brazilian wild captive felids. JWildl Dis 2010; 46(3): 1017-1023. http:// dx.doi.org/10.7589/0090-3558-46.3.1017. PMid:20688716.

André MR, Denardi NCB, Sousa KCM, Gonçalves LR, Henrique PC, Ontivero CRGR, et al. Arthropod-borne pathogens circulating in freeroaming domestic cats in a zoo environment in Brazil. Ticks Tick Borne Dis 2014; 5(5): 545-551. http://dx.doi.org/10.1016/j.ttbdis.2014.03.011. PMid:24889035.

André MR, Dumler JS, Scorpio DG, Teixeira RHF, Allegretti SM, Machado RZ. Molecular detection of tick-borne bacterial agents in Brazilian and exotic captive carnivores. Ticks Tick Borne Dis 2012; 3(4): 247-253. http:// dx.doi.org/10.1016/j.ttbdis.2012.04.002. PMid:22749737.

André MR, Filgueira KD, Calchi AC, Sousa KCM, Gonçalves LR, Medeiros VB, et al. Co-infection with arthropod-borne pathogens in domestic cats. Rev Bras Parasitol Vet 2017; 26(4): 525-531. http://dx.doi. org/10.1590/s1984-29612017064. PMid:29160357.

André MR, Herrera HM, Fernandes SJ, Sousa KCM, Gonçalves LR, Domingos $\mathrm{IH}$, et al. Tick-borne agents in domesticated and stray cats from the city of Campo Grande, state of Mato Grosso do Sul, midwestern Brazil. Ticks Tick Borne Dis 2015; 6(6): 779-786. http://dx.doi.org/10.1016/j. ttbdis.2015.07.004. PMid:26187416.

André MR. Diversity of Anaplasma and Ehrlichia/Neoehrlichia agents in terrestrial wild carnivores worldwide: implications for human and domestic animal health and wildlife conservation. Front Vet Sci 2018; 5: 293. http://dx.doi.org/10.3389/fvets.2018.00293. PMid:30533417.

Baneth G, Bourdeau P, Bourdoiseau G, Bowman D, Breitschwerdt E, Capelli G, et al. Vector-borne diseases-constant challenge for practicing veterinarians: recommendations from the CVBD World Forum. Parasit Vectors 2012; 5(1): 55. http://dx.doi.org/10.1186/1756-3305-5-55. PMid:22433172.

Barros-Battesti DM, Arzua M, Bechara GH. Carrapatos de importância médico-veterinária da região neotropical: um guia ilustrado para identificação de espécies. 1. ed. São Paulo: Vox ICTTD-3 Butantan; 2006.

Benevenute JL, Dumler JS, Ogrzewalska M, Roque ALR, Mello VVC, Sousa KCM, et al. Assessment of a quantitative 5' nuclease real-time polymerase chain reaction using groEL gene for Ehrlichia and Anaplasma species in rodents in Brazil. Ticks Tick Borne Dis 2017; 8(4): 646-656. http://dx.doi.org/10.1016/j.ttbdis.2017.04.011. PMid:28457822.

Bicho CL, Ribeiro PB. Chave Pictórica para as Principais Espécies de Siphonaptera de Importância Médica e Veterinária, no Brasil. Rev Bras Parasitol Vet 1998; 7(1): 47-51.

Billeter SA, Gundi VAKB, Rood MP, Kosoy MY. Molecular Detection and Identification of Bartonella Species in Xenopsylla cheopis Fleas (Siphonaptera: Pulicidae) Collected from Rattus norvegicus Rats in Los Angeles, California. Appl Environ Microbiol 2011; 77(21): 7850-7852. http://dx.doi.org/10.1128/AEM.06012-11. PMid:21908631.

Birkenheuer AJ, Levy MG, Breitschwerdt EB. Development and evaluation of a seminested PCR for detection and differentiation of Babesia gibsoni (Asian genotype) and B. canis DNA in canine blood samples. J Clin Microbiol 2003; 41(9): 4172-4177. http://dx.doi.org/10.1128/ JCM.41.9.4172-4177.2003. PMid:12958243.

Birkenheuer AJ, Marr H, Alleman AR, Levy MG, Breitschwerdt EB. Development and evaluation of a PCR assay for the detection of Cytauxzoon felis DNA in feline blood samples. Vet Parasitol 2006; 137(1-2): 144149. http://dx.doi.org/10.1016/j.vetpar.2005.12.007. PMid:16417970.

Bortoli CP, André MR, Braga MSC, Machado RZ. Molecular characterization of Hepatozoon sp. in cats from São Luís Island, Maranhão, Northeastern Brazil. Parasitol Res 2011; 109(4): 1189-1192. http://dx.doi.org/10.1007/ s00436-011-2376-6. PMid:21607692.

Bouer A, André MR, Gonçalves LR, Luzzi MC, Oliveira JP, Rodrigues AC, et al. Hepatozoon caimani in Caiman crocodilus yacare (Crocodylia, Alligatoridae) from North Pantanal, Brazil. Rev Bras Parasitol Vet 2017; 26(3): 352-358. http://dx.doi.org/10.1590/s1984-29612017041. PMid:28902260.

Braga AR, Corrêa AP, Camossi LG, Silva RC, Langoni H, Lucheis SB. Coinfection by Toxoplasma gondii and Leishmania spp. in domestic cats (Felis catus) in State of Mato Grosso do Sul. Rev Soc Bras Med Trop 2014a; 47(6): 796-797. http://dx.doi.org/10.1590/0037-8682-00412014. PMid:25626663.

Braga ÍA, Santos LGF, Ramos DGS, Melo ALT, Mestre GLC, Aguiar DM. Detection of Ehrlichia canis in domestic cats in the central-western region of Brazil. Braz J Microbiol 2014b; 45(2): 641-645. http://dx.doi. org/10.1590/S1517-83822014000200036. PMid:25242952.

Braga IA, Dias IS, Chitarra CS, Amude AM, Aguiar DM. Molecular detection of Bartonella clarridgeiae in domestic cats from Midwest Brazil. Braz J Infect Dis 2015; 19(4): 451-452. http://dx.doi.org/10.1016/j. bjid.2015.05.002. PMid:26100436.

Braga IA, Santos LG, Melo AL, Jaune FW, Ziliani TF, Girardi AF, et al. Hematological values associated to the serological and molecular diagnostic in cats suspected of Ehrlichia canis infection. Rev Bras Parasitol Vet 2013; 22(4): 470-474. http://dx.doi.org/10.1590/S1984-29612013000400005. PMid:24473870.

Braga IA, Ramos DGS, Marcili A, Melo ALT, Taques IIGG, Amude AM, et al. Molecular detection of tick-borne protozoan parasites in a population of domestic cats in midwestern Brazil. Ticks Tick Borne Dis 2016; 7(5): 1004-1009. http://dx.doi.org/10.1016/j.ttbdis.2016.05.007. PMid:27260253.

Braga MSCO, Diniz PP, André MR, Bortoli CP, Machado RZ. Molecular characterisation of Bartonella species in cats from São Luís, state of Maranhão, north-eastern Brazil. Mem Inst Oswaldo Cruz 2012a; 107(6): 772-777. http://dx.doi.org/10.1590/S0074-02762012000600011. PMid:22990968. 
Braga MSCO, André MR, Freschi CR, Teixeira MCA, Machado RZ. Molecular detection oh hemoplasma infection among cats from São Luís Island, Maranhão, Brazil. Braz J Microbiol 2012b; 43(2): 569-575. http:// dx.doi.org/10.1590/S1517-83822012000200018. PMid:24031865.

Chomel BB, Kasten RW. Bartonellosis, an increasingly recognized zoonosis. J Appl Microbiol2010; 109(3): 743-750. http://dx.doi.org/10.1111/j.13652672.2010.04679.x. PMid:20148999.

Coura FM, Passos SKF, Pelegrino MOF, Leme FOP, Paz GF, Gontijo CMF, et al. Serological, molecular, and microscopic detection of Leishmania in cats (Felis catus) in Belo Horizonte, Minas Gerais State, Brazil. Rev Bras Parasitol Vet 2018; 27(4): 570-574. http://dx.doi.org/10.1590/ s1984-296120180052. PMid:30183999.

Diniz PP, Maggi RG, Schwartz DS, Cadenas MB, Bradley JM, Hegarty $\mathrm{B}$, et al. Canine bartonellosis: serological and molecular prevalence in Brazil and evidence of co-infection with Bartonella henselae and Bartonella vinsonii subsp. berkhoffii. Vet Res 2007; 38(5): 697-710. http://dx.doi. org/10.1051/vetres:2007023. PMid:17583666.

Drazenovich N, Foley J, Brown RN. Use of real-time quantitative PCR targeting the msp2 protein gene to identify cryptic Anaplasma phagocytophilum infections in wildlife and domestic animals. Vector Borne Zoonotic Dis 2006; 6(1): 83-90. http://dx.doi.org/10.1089/vbz.2006.6.83. PMid:16584330.

Eyer-Silva WA, Soares PEMA, Azevedo MCVM, Silva GARD, Signorini DJHP, Neves-Motta R, et al. An unusual case of bacillary angiomatosis in the oral cavity of an AIDS patient who had no concomitant tegumentary lesions - case report and review. Rev Inst Med Trop São Paulo 2017; 59(0): e59. http://dx.doi.org/10.1590/s1678-9946201759059. PMid:28902296.

Figueiredo FB, Lima FEF Jr, Tomio JE, Indá FMC, Corrêa GLB, Madeira MF. Leishmaniose Visceral Canina: dois casos autóctones no município de Florianópolis, Estado de Santa Catarina. Acta Sci Vet 2012; 40(1): 1026-1029.

Filoni C, Catão-Dias JL, Cattori V, Willi B, Meli ML, Corrêa SH, et al. Surveillance using serological and molecular methods for the detection of infectious agents in captive Brazilian neotropic and exotic felids.J Vet Diagn Invest 2012; 24(1): 166-173. http://dx.doi.org/10.1177/1040638711407684. PMid:21908268.

Furtado MM, Taniwaki SA, Metzger B, Paduan KS, O'Dwyer HL, Jácomo ATA, et al. Is the free-ranging jaguar (Panthera onca) a reservoir for Cytauxzoon felis in Brazil? Ticks Tick Borne Dis 2017; 8(4): 470-476. http://dx.doi.org/10.1016/j.ttbdis.2017.02.005. PMid:28196774.

Gonçalves LR, Roque AL, Matos CA, Fernandes SJ, Olmos ID, Machado RZ, et al. Diversity and molecular characterization of novel hemoplasmas infecting wild rodents from different Brazilian biomes. Comp Immunol Microbiol Infect Dis 2015; 43: 50-56. http://dx.doi.org/10.1016/j. cimid.2015.10.006. PMid:26616660.

Guimarães A, Raimundo JM, Rodrigues RB, Peixoto MP, Santos HA, André MR, et al. Ehrlichia spp. infection in domestic cats from Rio de Janeiro State, southeast Brazil. Rev Bras Parasitol Vet 2019; 28(1): 180 185. http://dx.doi.org/10.1590/s1984-296120180088. PMid:30892460.

Hartmann K, Bergmann M. Vector-borne diseases in cats in Germany. Tierarztl Prax Ausg K Kleintiere Heimtiere 2017; 45(5): 329-335. http:// dx.doi.org/10.15654/TPK-160874. PMid:28905982.

Inokuma H, Okuda M, Ohno K, Shimoda K, Onishi T. Analysis of the 18S rRNA gene sequence of a Hepatozoon detected in two Japanese dogs. Vet Parasitol 2002; 106(3): 265-271. http://dx.doi.org/10.1016/ S0304-4017(02)00065-1. PMid:12062514.
Jefferies R, Ryan UM, Irwin PJ. PCR-RFLP for the detection and differentiation of the canine piroplasm species and its use with filter paper-based technologies. Vet Parasitol 2007; 144(1-2): 20-27. http:// dx.doi.org/10.1016/j.vetpar.2006.09.022. PMid:17127005.

Jusi MMG, Oliveira TMFS, Nakaghi AC, André MR, Machado RZ. Expression of a recombinant protein, A2 family, from Leishmania infantum (Jaboticabal strain) and its evaluation in Canine Visceral Leishmaniasis serological test. Rev Bras Parasitol Vet 2015; 24(3): 309-316. http://dx.doi. org/10.1590/S1984-29612015060. PMid:26444061.

Katoh K, Standley DM. MAFFT multiple sequence alignment software version 7: improvements in performance and usability. Mol Biol Evol 2013; 30(4): 772-780. http://dx.doi.org/10.1093/molbev/mst010. PMid:23329690.

Longoni SS, López-Cespedes A, Sánchez-Moreno M, Bolio-Gonzalez ME, Sauri-Arceo CH, Rodríguez-Vivas RI, et al. Detection of different Leishmania spp. and Trypanosoma cruzi antibodies in cats from the Yucatan Peninsula (Mexico) using an iron superoxide dismutase excreted as antigen. Comp Immunol Microbiol Infect Dis 2012; 35(5): 469-476. http://dx.doi.org/10.1016/j.cimid.2012.04.003. PMid:22560557.

Lopes EG, Geraldo CA Jr, Marcili A, Silva RD, Keid LB, Oliveira TMFS, et al. Performance of conventional PCRs based on primers directed to nuclear and mitochondrial genes for the detection and identification of Leishmania spp. Rev Inst Med Trop São Paulo 2016; 58: 41. http://dx.doi. org/10.1590/S1678-9946201658041. PMid:27253743.

Machado RZ, André MR, Werther K, Souza E, Gavioli FA, Alves RF Jr. Migratory and Carnivorous Birds in Brazil: reservoirs for Anaplasma and Ehrlichia Species? Vector Borne Zoonotic Dis 2012; 12(8): 705-708. http://dx.doi.org/10.1089/vbz.2011.0803. PMid:22607070.

Maggi RG, Chitwood MC, Kennedy-Stoskopf S, DePerno CS. Novel hemotropic Mycoplasma species in white-tailed deer (Odocoileus virginianus). Comp Immunol Microbiol Infect Dis 2013; 36(6): 607-611. http://dx.doi. org/10.1016/j.cimid.2013.08.001. PMid:24018179.

Maia C, Ramos C, Coimbra M, Bastos F, Martins A, Pinto P, et al. Bacterial and protozoal agents of feline vector-borne diseases in domestic and stray cats from southern Portugal. Parasit Vectors 2014; 7(1): 115 http://dx.doi.org/10.1186/1756-3305-7-115. PMid:24655431.

Maia LMP, Cerqueira AMF, Macieira DB, Souza AM, Moreira NS, Silva AV, et al. Cytauxzoon felis and 'Candidatus Mycoplasma haemominutum' coinfection in a Brazilian domestic cat (Felis catus). Rev Bras Parasitol Vet 2013; 22(2): 289-291. http://dx.doi.org/10.1590/S1984-29612013000200049. PMid:23856727.

Malheiros J, Costa MM, Amaral RB, Sousa KCM, André MR, Machado $\mathrm{RZ}$, et al. Identification of vector-borne pathogens in dogs and cats from Southern Brazil. Ticks Tick Borne Dis 2016; 7(5): 893-900. http://dx.doi. org/10.1016/j.ttbdis.2016.04.007. PMid:27266811.

Massung RF, Slater K, Owens JH, Nicholson WL, Mather TN, Solberg VB, et al. Nested PCR assay for detection of granulocytic ehrlichiae. $J$ Clin Microbiol 1998; 36(4): 1090-1095. PMid:9542943.

Miceli NG, Gavioli FA, Gonçalves LR, André MR, Sousa VR, Sousa $\mathrm{KC}$, et al. Molecular detection of feline arthropod-borne pathogens in cats in Cuiabá, state of Mato Grosso, central-western region of Brazil. Rev Bras Parasitol Vet 2013; 22(3): 385-390. http://dx.doi.org/10.1590/ S1984-29612013000300011. PMid:24142170.

Miller MA. CIPRES science gateway survey results [online]. 2010 [cited 2019 Mar 05]. Available from: http://www.phylo.org/tools/survey2.html 
Murphy GL, Ewing SA, Whitworth LC, Fox JC, Kocan AA. A molecular and serologic survey of Ehrlichia canis, E. chaffeensis and E. ewingii in dogs and ticks from Oklahoma. Vet Parasitol 1998; 79(4): 325-339. http://dx.doi.org/10.1016/S0304-4017(98)00179-4. PMid:9831955.

Nakaghi ACH, Machado RZ, Costa MT, André MR, Baldani CD. Erliquiose canina: aspectos clínicos, hematológicos, sorológicos e moleculares. Cienc Rural 2008; 38(3): 766-770. http://dx.doi.org/10.1590/ S0103-84782008000300027.

Oliveira TMFS, Furuta PI, Carvalho D, Machado RZ. A study of cross-reactivity in serum samples from dogs positive for Leishmania spp., Babesia canis and Ehrlichia canis in enzyme-linked immunosorbent assay and indirect fluorescent antibody test. Rev Bras Parasitol Vet 2008; 17(1): 7-11. http://dx.doi.org/10.1590/S1984-29612008000100002. PMid:18554433.

Ortuño A, Gauss CB, García F, Gutierrez JF. Serological evidence of Ehrlichia spp. exposure in cats from northeastern Spain. J Vet Med $B$ Infect Dis Vet Public Health 2005; 52(5): 246-248. http://dx.doi. org/10.1111/j.1439-0450.2005.00849.x. PMid:16115100.

Otranto D, Dantas-Torres F. Canine and feline vector-borne diseases in Italy: current situation and perspectives. Parasit Vectors 2010; 3(1): 2. http://dx.doi.org/10.1186/1756-3305-3-2. PMid:20145730.

Paziewska A, Harris PD, Zwolińska L, Bajer A, Siński E. Recombination within and between species of the alpha proteobacterium Bartonella infecting rodents. Microb Ecol 2011; 61(1): 134-145. http://dx.doi. org/10.1007/s00248-010-9735-1. PMid:20740281.

Peixoto PV, Soares CO, Scofield A, Santiago CD, França TN, Barros SS. Fatal cytauxzoonosis in captive-reared lions in Brazil. Vet Parasitol 2007; 145(3-4): 383-387. http://dx.doi.org/10.1016/j.vetpar.2006.12.023. PMid:17306459.

Pennisi MG, Hofmann-Lehmann R, Radford AD, Tasker S, Belák S, Addie DD, et al. Anaplasma, Ehrlichia and Rickettsia species infections in cats: european guidelines from the ABCD on prevention and management. J Feline Med Surg 2017; 19(5): 542-548. http://dx.doi. org/10.1177/1098612X17706462. PMid:28438088.

Pennisi MG, Marsilio F, Hartmann K, Lloret A, Addie D, Belák S, et al. Bartonella species infection in cats: ABCD guidelines on prevention and management. J Feline Med Surg 2013; 15(7): 563-569. http://dx.doi. org/10.1177/1098612X13489214. PMid:23813816.

Pennisi MG, Persichetti MF. Feline leishmaniosis: is the cat a small dog? Vet Parasitol 2018; 251: 131-137. http://dx.doi.org/10.1016/j. vetpar.2018.01.012. PMid:29426470.

Pitassi LH, Diniz PPP, Scorpio DG, Drummond MR, Lania BG, Barjas-Castro ML, et al. Bartonella spp. bacteremia in blood donors from Campinas, Brazil. PLoS Negl Trop Dis 2015; 9(1): e0003467. http:// dx.doi.org/10.1371/journal.pntd.0003467. PMid:25590435.

Raimundo JM, Guimarães A, Amaro GM, Silva AT, Botelho CFM, Massard CL, et al. Molecular survey of Bartonella species in shelter cats in Rio de Janeiro: Clinical, Hematological, and Risk Factors. Am J Trop Med Hyg 2019; 100(6): 1321-1327. http://dx.doi.org/10.4269/ ajtmh.18-0585. PMid:31017080.

Ristic M, Holland CJ. Canine ehrlichiosis. In: Woldehiwet Z, Ristic M, editors. Rickettsial and chlamydial diseases of domestic animals. Oxford: Pergamon; 1993. p. 169-186.
Rodgers MR, Popper SJ, Wirth DF. Amplification of kinetoplast DNA as a tool in the detection diagnosis of Leishmania. Exp Parasitol 1990; 71(3): 267-275. http://dx.doi.org/10.1016/0014-4894(90)90031-7. PMid:2170165.

Ronquist F, Huelsenbeck JP. MrBayes 3: bayesian phylogenetic inference under mixed models. Bioinformatics 2003; 19(12): 1572-1574. http:// dx.doi.org/10.1093/bioinformatics/btg180. PMid:12912839.

Santos AP, Santos RP, Biondo AW, Dora JM, Goldani LZ, Oliveira ST, et al. Hemoplasma infection in HIV-positive patient, Brazil. Emerg Infect Dis 2008; 14(12): 1922-1924. http://dx.doi.org/10.3201/eid1412.080964. PMid:19046522.

Secretaria Municipal de Saúde. Alerta epidemiológico. Leishmaniose visceral humana [online]. 2017 [cited 2019 Mar 05]. Available from: http://www. pmf.sc.gov.br/arquivos/arquivos/pdf/14_12_2017_14.52.54.2be8663c b5c0d895f08fe96e401a304e.pdf

Shaw SE, Kenny MJ, Tasker S, Birtles RJ. Pathogen carriage by the cat flea Ctenocephalides felis (Bouché) in the United Kingdom. Vet Microbiol 2004; 102(3-4): 183-188. http://dx.doi.org/10.1016/j.vetmic.2004.06.013. PMid:15327793.

Silva MN, Vieira-Damiani G, Ericson ME, Gupta K, Gilioli R, Almeida AR, et al. Bartonella henselae transmission by blood transfusion in mice. Transfusion 2016; 56(6Pt2): 1556-1559. http://dx.doi.org/10.1111/ trf.13545. PMid:26968530.

Sousa KCM, Calchi AC, Herrera HM, Dumler JS, Barros-Battesti DM, Machado RZ, et al. Anaplasmataceae agents among wild mammals and ectoparasites in Brazil. Epidemiol Infect 2017; 145(16): 3424-3437. http:// dx.doi.org/10.1017/S095026881700245X. PMid:29103397.

Stöver BC, Muller KF. TreeGraph 2: combining and visualizing evidence from different phylogenetic analyses. BMC Bioinformatics 2010; 11(1): 7. http://dx.doi.org/10.1186/1471-2105-11-7. PMid:20051126.

Tasker S, Hofmann-Lehmann R, Belák S, Frymus T, Addie DD, Pennisi MG, et al. Haemoplasmosis in cats: european guidelines from the ABCD on prevention and management. J Feline Med Surg 2018; 20(3): 256261. http://dx.doi.org/10.1177/1098612X18758594. PMid:29478400.

Udell MAR, Shreve KRV. Editorial: feline behavior and cognition. Behav Processes 2017; 141(Pt3): 259-260. http://dx.doi.org/10.1016/j. beproc.2017.04.005. PMid:28416379.

Vieira-Damiani G, Diniz PP, Pitassi LH, Sowy S, Scorpio DG, Lania BG, et al. Bartonella clarridgeiae bacteremia detected in an asymptomatic blood donor. J Clin Microbiol 2015; 53(1): 352-356. http://dx.doi. org/10.1128/JCM.00934-14. PMid:25392353.

Weiss DJ, Wardrop JK. Schalm's veterinary hematology. Gth ed. Iowa; 2010.

Wen B, Rikihisa Y, Mott JM, Greene R, Kim HY, Zhi N, et al. Comparison of Nested PCR with immunofluorescent-antibody assay for detection of Ehrlichia canis infection in dogs treated with doxycycline. J Clin Microbiol 1997; 35(7): 1852-1855. PMid:9196207.

Werther K, Luzzi MC, Gonçalves LR, de Oliveira JP, Alves JRF Jr, Machado RZ, et al. Arthropod-borne agents in wild Orinoco geese (Neochen jubata) in Brazil. Comp Immunol Microbiol Infect Dis 2017; 55: 30-41. http:// dx.doi.org/10.1016/j.cimid.2017.09.003. PMid:29127991. 